\title{
Scale of radionuclide emission at the Chornobyl Nuclear Power Plant in 1986 (The analysis of estimations)
}

\author{
K.P.Checherov ${ }^{1}$, S.B.Kumshaev ${ }^{2}$, M.V.Tokarchuk ${ }^{3}$ \\ 1 The Russian Center of Science "Kurchatovsky institute", \\ 1 Acad. I.V.Kurchatov Sq., 123182 Moscow, Russia \\ 2 OP Analytical Center "Quality", 46 Science Avenue, 030128 Kyiv, Ukraine \\ 3 Institute for Condensed Matter Physics \\ of the National Academy of Sciences of Ukraine, \\ 1 Svientsitskii Str., 79011 Lviv, Ukraine
}

Received July 7, 2000

\begin{abstract}
How much fuel remained inside the Chornobyl Unit 4 after the accident? What is the scale of radionuclide emission in the environment? Till now these questions excite the scientific community of the world. The critical analysis of various points of view on a problem of radionuclide emission during the accident at Chornobyl NPP is proposed.
\end{abstract}

Key words: Chornobyl NPP, radionuclide emission, fuel containing masses, uranium, plutonium

PACS: $05.60 .+w, 28.20 . G d, 66.20 .+d$

One of the central scientific and political interests and activities of the academician, the member of Ukrainian Parliament I.R.Yukhnovskii are the problems connected with Chornobyl accident. Under his supervision there were investigated: conditions of nuclear fuel in the 4-th reactor [1-4] after the accident; physical and chemical processes of interaction of fuel-containing masses with water and a problems of hydrogen and radiolysis [3,5-7]; processes of radionuclide migration $[8,9]$ in the site "Shelter" ("Sarcophagus") and in aqueous solutions in the soil of the Chornobyl zone. Many of his scientific conclusions have proved to be true concerning the mechanisms of the destruction fuel-containing masses (FCM), an exit from them and accumulation of uranium, plutonium in aqueous solutions of the site "Shelter". Actually there are suggestions to use aqueous solutions for radionuclide extraction from the site "Shelter".

In the proposed article we want deal with one of the main questions which excites the public of the world till now. It is a question - how much nuclear fuel remained inside the Chornobyl Unit 4 nuclear power plant (ChNPP) after the accident? 
After the accident at ChNPP in 1986, various experts (from different countries) made estimations of the size of radionuclide emission, essentially differing in structure and in activity. So, according to an estimation [10] submitted to the meeting of experts MAGATE in August, 1986, (total emission of fission products (FP) without radionuclide noble gases $(\mathrm{RNG})$ ) has made emission $50 \mathrm{MCi}$, or $\sim 3,5 \%$ of total radionuclides in the reactor at the moment of the accident. That is to say the total radionuclide activity in the active zone at the moment of the accident was considered to be $\sim 1500 \mathrm{MCi}[11,12]$. One of the first hypothetical estimations of the emission was made 02.05 .86 [13], prior to the beginning of serious experimental research, "at the extreme scarcity of the initial information", the absence of data on radionuclide activity in the reactor at the moment of the accident, based on such a selected model according to which "from a reactor rather small part of fuel and FP" is thrown out only. It was clear, that in that case the technique of the approach predetermined the result. Not knowing about this model and the estimation of emission (made by A.A.Hrulev taking place in Moscow), made simultaneously in Kiev the initial general estimation of emission in the environment of fragmental elements has made up $\sim 80 \%[14]$.

In Chornobyl in May, 1986 a group of experts from Minsredmash of the former USSR accepted an estimation of emission for a limited territory around ChNPP which made up 15-25\% fragmental nuclides and fuel [15], thus it was considered that $65-75 \%$ of the quantity of the fuel which occurred in the reactor at the moment of the accident, according to calculations, there are in the territory limits around ChNPP, probably, 10-30\% out of them are in the shaft of the reactor, 10-40\% are in generator hall, $5 \%$ - are in a blockage balloon of emergency shut-down system (ESRS), about $25 \%$ are in the territory around ChNPP [15]. The same estimation of fuel emission, even stronger $-80 \%$ of loading of the active zone, was accepted by experts and it was marked later [16] that the emission of 3-5\% should be only in case of partial fusion of heat-emitting elements, that corresponded to Hrulev's 1986 [13] model, but the results of supervision did not convince of the validity of the model and the estimation of emission appropriate to it.

It is possible to present a few dozens estimations of the emergency emission, but it will not change (it will only confirm) the evidence of the fact: the uniform, conventional, strictly proved estimation of the emission is not present yet.

However it does not exclude a critical look at the reasons of the origin of inconsistency of the estimations. Such an attempt of the critical analysis of the available information according to real a size of emissions of radioactive substances and the scale of environmental contamination as the result of Chornobyl accident in 1986 is represented by A.Bolsunovsky's work [17]. In it, the attention, first of all, paid to the necessity of considering the full radionuclide list in the structure of emergency emission (the account of the contribution of the short time life of radionuclides with a half-life period from several hours up to several dozen days should enable us to estimate doze loading on the population in the first day and months after the accident more objectively) was, in particular, inverted. Second, the existing distinctions in estimations as total, and with division on nuclides emission in an environment, made 
by experts of various countries at different times were marked. Estimations differ 2-5 times for various nuclides. Third, it was underlined that there is a significant disorder in estimations of the emission of fuel for the limits of the reactor. These reasons have urged the author [17] to a conclusion about the necessity of revising the official value of radionuclide emission aside from the increases.

Really, the results of the calculations of the total activity of the fission products published before the accident at the end of the campaign RBMK-1000 gave the size $\sim 10 \mathrm{GCi}[18,19]$, and after the accident the estimations (the same authors) appeared to be almost one order less, $\sim 1500 \mathrm{MCi}[10,11]$. This divergence can be explained, for example, by the distinctions of the accounted set FP. It is obvious, that a more careful analysis of the data is necessary to reduce the disorder of estimations not only at the operating time FP, the difficulty also consists in the absence of authentic experimental data about the laws of distribution of these radionuclides in an environment.

As the majority of experts admit, that during the initial time a few weeks after the accident, the greatest danger to the population presented ${ }^{131} \mathrm{I}$ with a half-life period $\sim 8$ days. Some months after disintegration of iodine dominant there was a radioactivity of barium, cerium, ruthenium and zirconium. Today the basic problem consists in ${ }^{137} \mathrm{Cs},{ }^{90} \mathrm{Sr}$ (a half-life periods about 30 years), plutonium ${ }^{239} \mathrm{Pu}$ (a half-life periods 24116.5 years) and americium ${ }^{241} \mathrm{Am}$ (a half-life periods 432.2 years).

The official Soviet figure of the total radionuclide emission makes up approximately $50 \mathrm{MCi}$ and it was clearly marked that this figure does not include the activity of noble gases, why it was corrected for May 6, 1986. If in this estimation activity we include the short time life of nuclides it will increase a few times, approximately up to $200 \mathrm{MCi}$, and the total activity up to 5-10 GCi and over [20,21].

As emission was distributed throughout the globe. In other countries, the nuclide quantity thrown out in the atmosphere was measured as well. Proceeding from the measured radionuclides concentration in the atmosphere and knowing a wind to rise, using the appropriate computer programs, in several institutes the quantity of the nuclides thrown out worldwide was counted.

The results of calculations of the French, English and American studies on radionuclide emission in the environment [22-23] show (table 1) that the Soviet, English and American figures practically coincide, except for the emission ${ }^{239} \mathrm{~Np}$, (though the results of the American calculations essentially differ among themselves).

The official estimation of the emission of nuclear fuel for the limits of the reactor, submitted in the MAGATE report in 1986, made up 3-4\% from the full loading the reactor (190 t uranium), i.e. $\sim 6-8$ t. The estimation of emission of fuel in 15-20\% was rejected [24] as contradicting presentations about distribution of the fuel of the 4 -th unit after the accident (up to $95 \%$ of fuel is in the shaft of the reactor $[25,26]$ ).

In the reports of Complex Expedition IAE in 1990 the estimation of the weight of fuel in "Shelter": $135 \pm 30 \mathrm{t}$ (on uranium) in "lava-like" fuel-containing masses (LFCM) and up to 35-50 t as dust and fragments of fuel in the central hall [27-29] is given. Thus, the possible emission of fuel from the shaft of the reactor was implicitly 
Table 1. The estimation of radionuclide emission in the atmosphere as the result of Chornobyl accident in 1986. Settlement estimations of emission, MCi

\begin{tabular}{|l|l|l|l|l|l|l|}
\hline Nuclide & USSR & France & England & \multicolumn{3}{|c|}{ USA } \\
\hline \multicolumn{3}{|l|}{} & 1 & 2 & 3 \\
\hline${ }^{90} \mathrm{Sr}$ & 0.126 & & 0.216 & & 0.034 & 0.18 \\
\hline${ }^{103} \mathrm{Ru}$ & 3.21 & 1.65 & 3.24 & 0.81 & 0.72 & 3 \\
\hline${ }^{106} \mathrm{Ru}$ & 1.57 & 0.84 & 1.59 & 0.14 & 0.17 & 0.91 \\
\hline${ }^{131} \mathrm{I}$ & $7.3(13) *$ & & 7.29 & 45.9 & 36 & 7 \\
\hline${ }^{132} \mathrm{Te}$ & 1.29 & 0.62 & 1.3 & 9.99 & 5.3 & 2 \\
\hline${ }^{133} \mathrm{Xe}$ & 45.9 & & 45.1 & 175.5 & 120 & 45 \\
\hline${ }^{137} \mathrm{Cs}$ & $1.0(2)^{*}$ & 1.54 & 0.999 & 2.4 & 2.4 & 0.81 \\
\hline${ }^{144} \mathrm{Ce}$ & 2.42 & 0.021 & 2.4 & 0.14 & 0.14 & 2.5 \\
\hline${ }^{239} \mathrm{~Np}$ & 0.113 & & 1.188 & & & 3 \\
\hline
\end{tabular}

* In brackets the later published estimations of the Soviet experts are submitted.

appreciated up to $75 \mathrm{t}(\sim 39,5 \%)$. In 1992 the estimation of the quantity of fuel in LFCM have got even a greater disorder up to $40 \%$ [30] that corresponded to the weight of uranium in LFCM from 81 up to 189 t, supposing the size of emission from 0 up to $43 \%$.

In the text of the Memorandum of the international symposium of 1994 "Safety of Shelter-94" it is mentioned that the quantity of nuclear fuel inside the 4-th unit is estimated in the interval from 27 up to $135 \mathrm{t}$ [31]. Thus, the worst estimation of the quantity of the thrown out fuel can make up $163 \mathrm{t}$, or $\sim 86 \%$. The results of the research executed by NIKIET and RSTC KI employees [32], show that in the found out congestions LFCM inside the site "Shelter" there is revealed approximately 10$15 \%$ of fuel from the initial loading of the reactor. Thus, to speak about authentically established size of the emission of nuclear fuel from a reactor during the accident there is no real experimental basis. The balance of nuclear fuel 4 units ChNPP inside and outside the site "Shelter" is not shown till now [33,34], and this conclusion for a long time became the property of the international scientific community.

The report of the English experts [22] prepared in 1987, contains (regarding radioactive emission) the comparative data according to the radionuclide contents in the fuel at the moment of the accident, submitted by Soviet Union in MAGATE in 1986 and calculated with the computer code FISPIN. The basic attention of the English experts was inverted to the most important forecast of radiating consequences of radionuclide accident. The results of the analysis testify that the estimation of the contents in nuclide fuel cesium $\left({ }^{134} \mathrm{Cs},{ }^{136} \mathrm{Cs},{ }^{137} \mathrm{Cs}\right)$, ruthenium $-{ }^{106} \mathrm{Ru}$ a little and neptunium $-{ }^{239} \mathrm{~Np}$, received by the Soviet experts, misses in comparison with the results of the English experts, and the estimations of the contents in the fuel of the other radionuclides are in good consent. The English experts criticize the official value of the total radionuclide emission on the first day of the accident $(15 \mathrm{MCi})$, including a settlement mistake, and, correcting a mistake of the Soviet experts, the 
Table 2. The contents in a reactor, $\mathrm{MCi}$

\begin{tabular}{|c|c|c|c|c|c|c|c|c|c|}
\hline Nuclide & USSR & France & German & Sweden & \multicolumn{2}{|c|}{ England } & \multicolumn{3}{|c|}{ USA } \\
\hline & & & & & 1 & 2 & 1 & 2 & 3 \\
\hline${ }^{90} \mathrm{Sr}$ & 5.4 & 2.2 & 6.2 & & 0.3 & 5.1 & 3.8 & & 4.6 \\
\hline${ }^{103} \mathrm{Ru}$ & 133 & 97.2 & 129.6 & 37.8 & 104 & 118 & & 111 & 140 \\
\hline${ }^{106} \mathrm{Ru}$ & 54 & 13 & 34.2 & & 118 & 25 & 25 & & 32 \\
\hline${ }^{131} \mathrm{I}$ & 85 & 62.1 & 67.4 & 27 & 72 & 80 & 84 & 81 & 82 \\
\hline${ }^{132} \mathrm{Te}$ & 90 & 67.5 & 57 & 37.8 & 107 & 111 & 119 & & 111 \\
\hline${ }^{133} \mathrm{Xe}$ & 196 & 140 & & & & 178 & 170 & & 168 \\
\hline${ }^{137} \mathrm{Cs}$ & 7.8 & 2.5 & 8.3 & 1.4 & 3.9 & 6.5 & 4.6 & & 6.2 \\
\hline${ }^{144} \mathrm{Ce}$ & 86 & 59 & 114 & & 77 & 105 & 84 & & 93 \\
\hline${ }^{239} \mathrm{~Np}$ & 86 & 567 & 570 & 513 & 1372 & 1276 & 1647 & & 180 \\
\hline${ }^{239} \mathrm{Pu}$ & 0.023 & 0.0017 & 0.0244 & & & 0.02 & 0.02 & & 0.26 \\
\hline
\end{tabular}

resulting size of emission in $40 \mathrm{MCi}$.

In all cases the initial information on the emergency source of radionuclide emission is the estimation of radionuclide quantity in the reactor at the moment of the accident. The results of calculations of the contents of some important radionuclides in the fuel of the reactor 4 blocks Chornobyl APP for the April 26, 1986, executed by experts of different countries [22-23,35] are given in tables 2 and 3 .

The data submitted in table 2, testify, that the disorder of the results for the same nuclides can reach several times, and for ${ }^{239} \mathrm{~Np}$ and ${ }^{239} \mathrm{Pu}$ even orders. The disorder of settlement estimations of the radionuclide contents in a reactor is one of the reasons of the disorder of estimations of emergency radionuclide emission. A.Sich's thesis [23] is based on experimental data and estimations received by him from some employees of Complex Expedition I.V.Kurchatov's IAE in Chornobyl, the conclusions made in the work, apparently, in a greater degree reflect the opinion of these employees.

Significant differences of settlement estimations of the radionuclide contents in the fuel (according to the official data given 1986) from other estimations are observed for ${ }^{106} \mathrm{Ru}$ - is overestimated $\sim 2$ times, ${ }^{239} \mathrm{~Np}$ - is underestimated $\sim 20$ times (in comparison with the Begichev's estimations (1990) [35] and Sich's (1993) [23]). Estimations of a relative radionuclide exit in an environment (given in [23] in table VI.6 (report MAGATE, 1986) and in table VI.7 (estimations of experts of England, France, Canada, Livermor laboratories of USA, NRC USA)) which are systematized in table 4 , in the most part are comparable.

Apparently, from table 4, the maximal estimations (exceeding the average on an exit of iodine 3-5 times and on an exit of strontium on 1-2 order), are given by the Canadian experts. Clearly, that calculation of exit FP in a strongly depends on the accepted model of the development of the processes of the accident and the thermal parameters appropriate to it, in particular. 
Table 3. The contents in a reactor, $\mathrm{MCi}$

\begin{tabular}{|l|l|l|l|l|l|l|}
\hline Nuclide & $\begin{array}{l}\text { USSR } \\
1986(1991)\end{array}$ & $\begin{array}{l}\text { MAGATE } \\
1986(1987)\end{array}$ & $\begin{array}{l}\text { Kirchner } \\
1988\end{array}$ & $\begin{array}{l}\text { Borovoj } \\
1989\end{array}$ & $\begin{array}{l}\text { Begichev } \\
1990\end{array}$ & $\begin{array}{l}\text { Sich } \\
1993\end{array}$ \\
\hline${ }^{90} \mathrm{Sr}$ & 6.0 & 5.4 & 6.2 & 6.0 & 6.158 & 6.16 \\
\hline${ }^{103} \mathrm{Ru}$ & 130 & 130 & 130 & & & 102 \\
\hline${ }^{106} \mathrm{Ru}$ & 60 & 54 & 34 & & 23.2 & 23.2 \\
\hline${ }^{131} \mathrm{I}$ & 86 & 85 & 67 & & & 83.2 \\
\hline${ }^{132} \mathrm{Te}$ & 73 & 90 & 57 & & & 121 \\
\hline${ }^{133} \mathrm{Xe}$ & 170 & 200 & & & & 176 \\
\hline${ }^{137} \mathrm{Cs}$ & 7.7 & 7.8 & 8.2 & 7.0 & 7.02 & 7.01 \\
\hline${ }^{144} \mathrm{Ce}$ & 90 & 86 & 110 & & 106 & 106 \\
\hline${ }^{239} \mathrm{~Np}$ & 720 & 98 & 570 & & 1567 & 1570 \\
\hline${ }^{239} \mathrm{Pu}$ & 0.023 & 0.023 & 0.024 & 0.026 & 0.02562 & 0.0256 \\
\hline
\end{tabular}

Table 4. The estimation of exit radionuclides at the accident on 4 block Chernobyl APP.

\begin{tabular}{|l|l|l|l|l|l|l|}
\hline Elements & USSR & England & France & Canada & \multicolumn{2}{|c|}{ USA } \\
\hline \multicolumn{9}{|c|}{} & LLNL & NRC \\
\hline RNG & 100.0 & much & - & - & $50-100$ & 100 \\
\hline I & 20.0 & $15-20$ & - & 75 & $12-60^{131} \mathrm{I}$ & 20 \\
\hline $\mathrm{Cs}$ & 13.0 & $15-20$ & 20 & 16 & $14-86^{137} \mathrm{Cs}$ & 20 \\
\hline $\mathrm{Te}$ & 15.0 & little & 7 & - & - & 3 \\
\hline $\mathrm{Ru}$ & 2.9 & 1 & $1-2$ & - & - & $0.3-0.4$ \\
\hline $\mathrm{Sr}$ & 4.0 & little & - & 16 & $0 / 01-1^{90} \mathrm{Sr}$ & - \\
\hline $\mathrm{Ba}$ & 5.6 & little & - & - & - & $0.4-0.7$ \\
\hline $\mathrm{La}$ & - & little & $0.01-0.04$ & - & - & $0.06-0.2$ \\
\hline $\mathrm{Np}$ & 3.2 & little & $0.02-0.04$ & - & - & $0.04-0.1$ \\
\hline
\end{tabular}


Based on the presentations about gradual heat-up fuel and fusion of a part of the active zone (in essence, Hrulev's model). A.Sich draws the conclusions which are distinct from estimations of Hrulev's: the exit ${ }^{137} \mathrm{Cs}$ has made up $35 \%$ from the contained in the reactor at the moment of the accident (the first official figure $13 \%$, later of $26 \%$ ) and the total exit of radioactive substances in the environment (excepting noble gases) has made size $4-5$ times bigger than it is given in MAGATE report in 1986 (50 MCi), i.e. 200-250 MCi.

Really, in May, 1986 calculations [36] according to which one month after the accident from the nuclear fuel of the 4-th unit should "leave" (or depart) a minimum of $80 \%$ Cs - a maximum of $100 \%$ Cs were executed. Nevertheless, there was claimed an exit ${ }^{137} \mathrm{Cs}$ all over again $\sim 13 \%$, then in an interval of $20-40 \%$, and a total radionuclide exit (without $\mathrm{RBG}$ ) with the account for the short time life of isotopes $\sim 200-250 \mathrm{MCi}$, i.e. estimations of emergency emission, basically, are the expert, at the best, supported calculations, which demand a more strict substantiation.

A special place is occupied by the estimations of plutonium emission. The results of experimental research GEOCHIM in May-June 1986 were characterized by some experts as erroneous [24]. However, actually, their authors' estimation was confirmed and later $[37,38]$ and if these estimations are true, emission FP only in the territory investigated by them can be up to $\sim 8 \%$, and we can see they are fixed in all countries of northern hemisphere [38].

Thus, the comparative analysis of radioactive emission as the result of the accident, allows us to draw the following conclusions:

1. The final estimation of radionuclide emission during the accident, according to various authors, is not verified and not measured. They are only variants of expert estimations.

2. Distinctions in estimations of radionuclide quantity in the reactor at the moment of the accident should explain methodical errors in settlement programs and the inconsistency of the initial data.

3. In the estimations of the size of emission in an environment (where it does not concern simple mistakes) it is possible to explain the distinctions aprioristic uncertainty and not the account for many physical and chemical processes at a heavy accident in conditions of the atomic power station with RBMK.

4. The estimation of the quantity of the thrown out fuel in many respects can be explained during the further works on the site "Shelter".

5. Revision of the official data on the size of radionuclide emission as the result of Chornobyl accident, undoubtedly, is necessary. However more objective data than in MAGATE report in 1986, the information should generalize, within the framework of the international cooperation, the saved up experience of experimental and settlement research of the behaviour and the interaction of fuel, radionuclides, building designs, graphite, water etc. during heavy accidents. Now it is presented real.

One of us (M.T.) thanks the INTAS (Project INTAS-Ukraine 95-0133) for financial support. 


\section{References}

1. Yukhnovskii I.R., Tokarchuk M.V. The problem of the 4th powerblock of Chornobyl NPS. I. Rewiev. Preprint ICMP-95-3U, Lviv, 1995, 40 p.

2. Yukhnovskii I.R., Kobryn O.E., Tokarevskii V.V., Tokarchuk M.V. Problems on interaction between water and fuel containing masses inside the object "Shelter" of Chornobyl Nuclear Power Plant. // J. Phys. Studies, 1997, vol. 1, No. 2, p. 169-180.

3. Yukhnovskii I.R., Tokarchuk M.V., Ignatyuk V.V. et al. Studies on noneqiulibrium physico- chemical processes in a system "fuel containing masses - aqueous solutions of radioactive elements". // Cond. Matt. Phys., 1997, No. 12, p. 63-96.

4. Kumshaev S.B., Checherov K.P., Tokarchuk M.V., Kobryn O.E. On the problems of monitoring of aqueous solutions of radioactive elements in the Alienation zone. I. The object "Shelter". Preprint ICMP-00-02U, Lviv, 2000, 26 p.

5. Yukhnovskii I.R., Tokarchuk M.V., Omelyan I.P., Sovyak E.M., Zhelem R.I. On the description of structural distribution and diffusion of radioactive elements in the system "glassy nuclear magma - water". // Cond. Matt. Phys., 1997, No. 9, p. 153-166.

6. Yukhnovskii I.R., Tokarchuk M.V., Zhelem R.I. Physical processes in the fuel containing masses interacting with aqueous solutions in the object "Shelter". Inhomogeneous diffusion of ions $\mathrm{UO}_{2}^{+2}, \mathrm{PuO}_{2}^{+2}, \mathrm{Cs}^{+}$in the system "glassy nuclear magma - water". // Cond.Matt.Phys., 1999, vol. 2, No. 2(18), p. 351-360.

7. Yukhnovskii I.R., Tokarchuk M.V., Kobryn O.E., Dmytriv G.S., Humenyuk Y.A. Analysis of chemical reactions of $\alpha$-radiolysis, hydrolysis and complex formation in alkali solutions of the object "Shelter". // J. Phys. Studies, 1999, vol. 3, No. 2, p. 224236.

8. Yukhnovskii I.R., Tokarchuk M.V., Omelyan I.P., Zhelem R.I. Statistical theory for diffusion radionuclides in ground and underground water I. Statistical model. Preprint ICMP-94-7E, Lviv, 1994, 19 p.

9. Yukhnovskii I.R., Tokarchuk M.V., Omelyan I.P., Zhelem R.I. Statistical theory for diffusion radionuclides in ground and subterranean. Preprint ICMP-98-35E, Lviv, 1998. $37 \mathrm{p}$.

10. Abagjan A.A., Asmolov V.G., Gus'kova A.K. et al. Accident at the Chornobyl atomic power station and its consequences. - In: The information prepared for meeting of experts MAGATE (August, 25-29, 1986, Vienna), Part 1, Generalized material, Moscow, GK IAE the USSR, 1986.

11. Sivintsev J.V. Radiation and the Person. Moscow, "Znanije", 1987, 64 p.

12. Lomakin V.V. The Chornobyl atomic power station: designing and construction, a safety. - In: "Chornobyl. Five difficult years", Moscow, 1992, p. 21.

13. Sivintsev J.V., Hrulev A.A. The estimation of radioactive emission at accident on the 4-th block Chornobyl APP. - In: The 4-th Annual scientific and technical conference JAO. Abstracts of conference. Nizhni Novgorod, 1993, p. 68-72.

14. Sobotovich E.V. The basic problems of geochemistry of radionuclides of Chornobyl emission. - In: "Chornobyl accident" (ed. Bar'jahtar V.G.), Kyiv, Naukova dumka, 1995, p. 199.

15. Pologih B.G., Kurnosov V.A., Aden V.G., Cherkashov J.M., Krasheninnikov I.S., Dubasov J.V., Rimskij-Korsakov A.A., Poljakov A.S. Information, Chornobyl, 24.05.1986, $4 \mathrm{p}$.

16. Jadrihinskij A.A. Nuclear accident on the 4-th block of the Chornobyl atomic power 
station and nuclear danger of reactors RBPC. - In: Inspection GAEN the USSR on the Kursk atomic power station. Kurchatov, 1989, 55 p.

17. Bolsunovsky A. About Revision of Scale of Radionuclide Emission as a Result of Chornobyl Accident. Krasnoyarsk, IBSB RAS, 1994.

18. Kulikov E.V., Legasov V.A., Rjazantsev E.P., Sidorenko V.A., Beljaev I.A., Demin V.F., Kryshev I.I., Kuz'min I.I. Nuclear power, safety and an environment. Preprint IAE-4286/3, Moscow, 1986, 32 p.

19. Babaev N.S., Demin V.F., Il'in L.A., Knizhnikov V.A., Kuz'min I.I., Legasov V.A., Sivintsev J.V. Nuclear power, the Person and an Environment. Moscow, Energoatomizdat, 1984.

20. The information on radiating questions in connection with accident on block No. 4 Chornobyl atomic power station. NIKIET, E 040-2728, Moscow, 1987, 51 p.

21. Dovbenko A.A., Smoljankina M.V., Stroganov A.A. Definition of nuclear-physical characteristics of fuel of the 4-th power unit of Chornobyl APP and radioactive emission of Chornobyl accident. Report IBRAE AN the USSR, Moscow, 1991, 29 p.

22. Gittus J.H. et al. The Chornobyl accident and its consequences \& NOR 4200. UK Atomic Energy Authority, London, March, 1987.

23. Sich A. The Chornobyl accident revisited: source term analysis and reconstruction of events during the active phase. (Submitted to the Department of Nuclear Engineering in Partial Fullfillment of the Requirements for the degree of Doctor Philosophy). Massachusets Institute of Technology, USA, 1994.

24. Beljaev C., Borovoj A., Gagarinsky A. What people in "Sarcophagus" do? - In: "The Nuclear trace" (ed. G.Malkin), Moscow, JAO USSR, Energoatomizdat, 1990, p. 49-54.

25. Feoktistov L.P., Beljaev S.T., Osmachkin V.S., Hrulev A.A., Asmolov V.G., Shah O.J. The information on spatial distribution of a radio-activity after accident on the 4-th block Chornobyl APP, 03.07.1986, 2 p.

26. The working documentation (design decisions), the Project of a burial place of the 4-th block Chornobyl APP, Gl. The case (reactor branch and generator hall), t. 1. Communicating an explanatory note, Leningrad, VNIPIET, 1986, 61 p.

27. Borovoj A.A. Settlement estimations on specification of a site of nuclear fuel in object "Shelter" on measurements 1988-1990. Report IAE No. 50.05/82, Moscow, 1990, 7 p.

28. Beljaev S.T., Borovoj A.A., Buzulukov J.P. Works on platform Chornobyl APP, the present and the future of the "Sarcophagus". - In: The elected works of the International conference "Nuclear accidents and the future of power. Lessons of Chornobyl", JAO USSR, Kurchatov IAE, Moscow, 1992, p. 37-58.

29. Borovoj A.A., Sivintsev J.V. Distribution of the rests of fuel in "Shelter". - In: "Chornobyl. Five Difficult Years". Moscow, 1992, p. 113-117.

30. The Description of Object "Shelter" and Requirements to Its Transformation. Minchornobyl' of Ukraine, NAS of Ukraine. Kyiv, Naukova dumka, 1992, 51 p.

31. Gotovchits G., Steinberg N. International Symposium "Sarcophagus Safety-94". Memorandum, March 18, Kyiv, 1994.

32. Novosel'skij O.J., Checherov K.P., Zhukov N.V. Specification of quantity of the nuclear fuel which is taking place inside the 4-th block of the Chornobyl atomic power station. NIKIET, No. 27.110. 001-4257, Moscow, 1992, 129 p.

33. Kiselev A.N. How many nuclear fuel is in lava-like fuel-containing masses of the 4-th block Chernobyl APP. // Atomic Energy, 1995, vol. 78, No. 4, p.

34. Kiselev A.N., Checherov K.P. Lava-like fuel-containing masses in Unit-4 of Chernobyl 
NPP. - In: Sixth Annual Scientific \& Technical Conference on the Nuclear Society "International Cooperation for Nuclear Development", Kyiv, Ukraine, 3-7 July 1995, Book of Abstracts, vol. 2, p. 306-314.

35. Begichev S.N., Borovoj A.A., Burlakov E.V. et al. Fuel of a reactor of the 4-th block Chornobyl APP. Preprint IAE-5268/3., Moscow, 1990, 21 p.

36. Feoktistov L.P., Chajvanov B.B., Duman E.L., Dorofeev S.B., Tishchenko N.P., Shmatov I.P. The Information on a Temperature Mode of a Reactor and Carrying out of Fission Products. Moscow, IAE, 1986, 15 p.

37. Lebedev I.A., Mjasoedov B.F., Pavlotskaja F.I., Frenkel' V.J. The contents of fission products and plutonium in ground the European part of the USSR after accident on Chornobyl NPP. // Geochemistry, 1993, No. 7, p. 948-954.

38. Barsukov V.L., Hitrov L.M. Radiogeochemical aspects of consequences of Chornobyl accident. // Geochemistry, 1993, No. 7, p. 918-924.

\title{
Масштаб викиду радіонуклідів на ЧАЕС у 1986 році (аналіз оцінок)
}

\author{
К.П.Чечеров ${ }^{1,2}$, С.Б.Кумшаєв ${ }^{2}$, М.В.Токарчук ${ }^{3}$ \\ 1 Російський науковий центр “Курчатовський інститут”, \\ 123182 Москва, пл. ак. І.В.Курчатова, 1 \\ 2 ОП Аналітичний центр “Якість", 03028 Київ, пр. Науки, 46 \\ 3 Інститут фізики конденсованих систем НАН України, \\ 79011 Львів, вул. Свєнціцького, 1
}

Отримано 7 липня 2000

Скільки палива залишилось всередині 4 блоку ЧАЕС після аварії? Який масштаб викиду радіонуклідів в оточуюче середовище? Такі питання й досі хвилюють наукову спільноту всього світу. Пропонується критичний аналіз різних точок зору на проблему викиду радіонуклідів у процесі аварії на Чорнобильській АЕС.

Ключові слова: Чорнобильська АEC, викид радіонуклідів, паливомісні маси, уран, плутоній

PACS: $05.60 .+w, 28.20 . G d, 66.20 .+d$ 